\title{
Ideological Education Plays An Important Role In The Construction Of Campus Culture
}

\author{
Meiyue $\mathrm{Li}^{1, \text { a }}$ \\ ${ }^{1}$ Xi'an Medical University, Xi'an, Shaanxi Province, China \\ a18278884@qq.com
}

Keywords: The ideological and political education, college campus culture, Construction

\begin{abstract}
With the development of China's higher education, college of education is more and more clear direction. In this case, the universities also gradually realize the ideological and political education and the construction of campus culture to the important meaning of talents cultivation. In this paper, starting from the connotation of campus culture interpretation, expounds its value function; On ideological and political education and the relationship of campus culture construction in detail, this paper reveals the important meaning of the two fusion; Finally put forward the corresponding fusion ways and countermeasures.
\end{abstract}

\section{Introduction}

Ideological and political education of humanities concern has scientific connotation and important value. The current ideological and political education in the humanities concern had certain into success, but there are also ignoring the individual differences and personality development, lack of humanistic education content and teaching method lag, marginalization of psychological counseling work, lack of social practice activities, the main reason is the result of education concept, ideological and political theory course teaching, psychological counseling work and ideological and political education team construction issues [1]. Do a good job in ideological and political education in the new period which runs through the humanistic care, pay attention to individual development and cultivate innovative talents, people-oriented, strengthen the service consciousness. Pay attention to the psychological counseling and improve the level of mental health. Need to pay attention to the humanistic spirit, building a harmonious campus cultural environment.

\section{The background analysis of humanistic care in the ideological and political education}

Social development reality calls for humanistic care. At present, China's socialist market economic system both human subjectivity of development provides the indispensable social and economic conditions, and make the human subjectivity of development problem appears more urgent [1]. The establishment and perfection of the market economy system requires people to greatly enhance the economic subject of subjectivity, get rid of and overcoming all personal relationships and the concept of attachment, enhance people's independent spirit and independent ability, enhance people's sense of self. Ideological and political education work to ensure the timeliness and effectiveness, it must adapt to the request of the socialist market economic system, pay attention to the humanistic care of college students in the education practice, and strive to carry forward and cultivate their subjectivity, the college students trained to be a strong subject consciousness, autonomy, self-reliance self-discipline character, strong will and fighting spirit, and dare to innovation and independent thinking of qualified builders of the socialist cause.

The needs of the contemporary college students' all-round development. The mainstream of contemporary college students' ideological and political situation is positive, healthy and upward, but the change of the situation at home and abroad, does have a huge impact on today's college students, the college students faces many challenges, the ideological and political education has met more and more difficulties and obstacles [2]. These problems mainly displays in: first, the international hostile forces in the ideological attack and socialist movement is at low ebb, it have taken place in the political beliefs of college students must be moved. Second, due to the invasion of western culture, 
values, and domestic social economic composition, social organization, social life style, the diversification of interests distribution and employment way, makes the value orientation of college student diversity. Third, as the study pressure, employment pressure and the pressure of social competition, some college students' psychological face problems more or less.

No reflect humanistic care education content and method. Education content to appear empty generalization and idealized [2]. For a long time, the content of the university ideological and political education (mainly the ideological and political theory course content) too much emphasis on the political significance of ideological and political education, the instrumental value, neglecting the students in the demand of all-round education and make the college students ideological and political education are high above the feeling, the same, there is no practical significance, and is the excellent member should to do, nothing to do with themselves seem to be.

Due to ignoring the students' subjectivity, inevitable in the process of ideological and political education has the tendency to mechanization. Some educators to ideological and political work of complicated object of ideology, morality, psychological quality improvement and simplification to resolve the problem, formalization and superficial, neglecting the students and the difference of the personality education, lack of democracy [3]. There are some who will process of intellectual education, ideological and political work often meet in theory lecture and indoctrination, ideological and political education should be colorful activities into the interpretation of knowledge about the ideological and political, teach and memory activities, ignored the all-round development of people, intelligence and physique, etc. It is because of the lack of humanistic care in the ideological and political education work, the effect of the contemporary ideological and political education work is not very satisfactory.

\section{Ideological and political education and the relationship of the campus culture construction}

From the point of the function of education in colleges, the construction of campus culture and ideological and political education is an important part of university students' work, they have a close relationship, and they promote each other and influence each other, mutual penetration.

The ideological and political education is the guiding role of campus culture construction direction. From the point of the object of the current ideological and political education, the education is the theme of the new generation of young college students, they are happy to accept new ideas, catch up with the new trend, and bold and creative, active thinking. The most fundamental goals of talents cultivation in colleges and universities is to cultivate students to be high quality talents, realize the comprehensive development of individuals [3]. Therefore, the construction of college campus culture must be consistent with the talents training goal of colleges and universities. This direction can't deviate from, without the guiding role of ideological and political education in colleges and universities. In the face of the new education group, the one-child majority, they showed a distinctive feature of this generation, such as: adhere to the mainstream value system, but influenced by pragmatism is more obvious; To the traditional moral ideas were high, has the strong moral consciousness, but also to some bad phenomenon has numbness, disregard attitude, affected by self-interest thinking; They attach importance to interpersonal relationships, for a variety of fashionable element is full of curiosity and passion, but often lead to irrational to blindly accept and so on. Therefore, to strengthen the construction of college campus culture, improve the comprehensive quality of college students, is not only the objective requirement to conform to the goal of personnel training in colleges and universities, and accord with the requirement of era to the construction of spiritual civilization. And therefore must be on the premise of the correct theory instruction, guided by the socialist ideology, firmly grasp the ideological and political education of the ground, to make the construction of campus culture reflect the direction of advanced culture actively, reflect social ideology to determine the fundamental value of the principles and orientation, lay a solid ideological foundation for the construction of campus culture in colleges and universities.

The construction of campus culture is conducive to the realization of the ideological and political education goals. First of all, the construction of campus culture is an effective way of ideological and political education work and important carrier. Excellent campus culture helps to 
guide students to establish correct world outlook, the outlook on life and values. The broad masses of young students in good campus culture atmosphere, consciously or unconsciously influenced by its influence, and incentives, and by selecting the process of education, self education, sublimation and improve themselves step by step, at the same time also makes the ideological and political education content and requirements are easy to be accepted by the young students. Second, Student activities in the specific campus cultural atmosphere, is affected by the influence and specific group consciousness, will be formed in this process is consistent with the group's cultural consciousness and character [4]. Austrian education historian Martin Cloth bell puts forward "the most important task for educators to help shape the character", "worthy of the name of education is character education" in essence, the emphasis is the campus culture shape function of students' ideology and moral character and personality. Health, elegant, positive campus culture is the student individuality free and harmonious development of the vast heaven and earth. In a multi-level, many forms of campus cultural activities, students can deeply realize your own value, develop potential individuality. As an important part of campus culture construction of the student club activities, to meet the needs of the student's communication, company, ownership and the development of interest and knowledge of specialty, open areas, perfect the cognitive structure has an irreplaceable role. On the part of the third, be helpful for students' mental health [4]. Campus culture with neat and beautiful campus environment, rich and colorful educational atmosphere of extra-curricular cultural life, full of youthful spirit, by infection, hint, cultivation, motivation and psychological adjustment and other functions, to improve the students' mentality, change students' mood, emotion, behavior norms and way of life, to cultivate the students' sentiment.

\section{Ideological and political education and campus culture construction ways and countermeasures}

Now of college students in the process of growth by diversified social background and the influence of many factors, such as family environment, has the characteristics of strong individual consciousness, innovation consciousness, but there is also a belief confusion, weak ideal and faith, the practical and utilitarian values, lack of collective idea, lack of social responsibility, psychology to bear ability is weak, lack of proper adjustment ability, etc. A good job must do in ideological and political education in the new period which runs through the humanities concern, exploration and innovation of ideological and political education in new initiatives.

Adhere to the ideological and political education to lead the construction of campus culture in the right direction. Ideological and political education on campus cultural construction has a certain guidance role in university culture construction also psychology and sound personality of college students have a certain impact [5]. Therefore, campus culture construction in colleges and universities need to grasp the correct value orientation, play of cognition and guidance of the campus culture on college students, so that the process of construction of college campus culture in fully embody the positive role of ideological and political education.

Consensus on giving full play to the advantages of the value orientation of campus culture. First of all, for ideological and political education, campus culture on the concept and value orientation has important advantages: through static and dynamic, materialized and latent campus culture construction, to make the ideological and political education main body on the concept of campus culture must position, which is truly strengthen ideological foundation for the notion of education effectiveness and environmental requirements. Campus culture atmosphere have a common consciousness and conception, to guarantee the unimpeded activities and common identity. Second, campus culture as a subculture, its development needs the spirit of the kernel, and advancing with The Times of ideological and political content will be constantly improving its internal requirement, condensed into campus culture thought core [5]. In addition to the excellent cultural tradition, the most important is the content of the contemporary social mainstream culture value system, such as the system of socialist core values for the construction of campus culture provides an important theoretical support. So, in the construction of campus culture, the effective use of the contents of the ideological and political education to determine the value orientation of campus 
culture, and also plays an important role for the ideological and political education. Anyhow, no matter from the identity of ideological and political education activities, or from the ideological and political education content stipulation of campus culture, campus culture on the values and obtains the actual effect of ideological and political education are displayed on the important guidance and location advantages.

Campus culture in order to increase the effectiveness of ideological and political education work. Various campus cultural activities constitute the dynamic carrier in the construction of college campus culture environment, also is the important aspect of campus culture construction [6]. In the process of various campus cultural activities, it is important to note must give full play to students' subjective role, students not only is the main part of the campus culture, is also the subject of ideological and political education, the construction of campus culture should fully respect the students' subjectivity, constantly give play to the important role of campus culture and ideological and political education, on the one hand, to continue to understand the students' psychological and interests, to carry out flavors of campus cultural activities for students, on the other hand, to fully arouse the enthusiasm of student cadres, on the premise of grasping the direction of the principle of the good, let student cadre planning, organizing various campus cultural activities, stimulate their creativity, so as to effectively promote the development of campus cultural activities, improve the work of ideological and political education in colleges and universities the effectiveness of the construction of campus cultural environment.

Rich campus culture construction, promote the ideological and political education. Environment of campus culture in colleges and universities have a strong educational function in the process of education, advanced campus culture environment for the students' mind, sentiment, world outlook, the outlook on life, the values of a extremely far-reaching impact, should be on the construction of campus culture in colleges and universities fully inherit and carry forward the national culture spirit, on the basis of widely useful to absorb and draw lessons from foreign culture, the constant innovation in the content and form [7]. That can be carried out in the past a variety of recreational activity, on the basis of innovative new carrier of the construction of campus culture environment, for example, introduce the network such as the carrier, in the premise of actively guide and control, give full play to the network environment on the construction of campus culture, but also make the network become important to promote the ideological and political education in institutions of higher learning. In addition, can strengthen the construction of the campus humanities environment and the natural environment, efforts to build up the good study and living environment, will the school motto of colleges and universities, Alma mater, crest, and materialized in various colleges and universities of architecture, sculpture, building plants such as campus landscape, effectively guide the university students to carry forward the fine tradition of colleges and universities.

Reform of the teaching system and strengthen the humanistic care education effectiveness. Human nature environment and cultural atmosphere, is a kind of invisible power, is the best carrier to strengthen college students' ideological and political education work. First, you need to adhere to the scientific outlook on development in the whole society, establish the people-oriented concept, handle the relationship between the construction of material civilization and spiritual civilization construction, overcoming the "commodity fetishism" brought about by the market economy "currency fetishism", and inhibit the utilitarian education. Second, must strengthen the family environment of education function [6]. Parents should strive to improve their own quality, set up the comprehensive development of quality education concept, forming a good start-up environment and harmonious family atmosphere, and make the child become the all-round development of comprehensive talent. Again, the construction of harmonious campus and achieve all-round education [7]. Faculty, staff, including management of administration, teaching, and logistics department personnel should have the deep cultural inside information, humanity and human feelings, plot the humanistic care and warmth to infiltrate the education teaching management of each link. Schools should actively build a healthy campus culture, subtly influence the healthy growth of students, and cultivate the students' noble personality. 


\section{Summary}

Ideological and political education as a kind of culture, shaping, influence, development of social education activities is the outstanding characteristic. In ideological and political education into the humanistic care is the need of the development of human nature, not only improve the effectiveness of ideological and political education work requirements, and promote students to achieve all-round development and the need of carrying out scientific development view. Therefore, in the process of ideological and political education into the humanistic care is of great practical significance. In the new situation, improve the actual effect of ideological and political education of institutions of higher learning.

\section{References}

[1] J. T. Hu, Holding the great banner of socialism with Chinese characteristics to struggle for the comprehensive construction affluent society new victory, Beijing: people's publishing house, 2007, vol. 10, pp. 3-6.

[2] D. L. Wang, The humanistic solicitude in ideological and political education resources, Zhejiang journal, 2005, vol. 3, pp. 220-223.

[3] B. Y. Liang, To further strengthen and improvement ideological and political education work, The education of China, 2005, vol. 3, pp. 14-19.

[4] B. T. Chen, The ministry of education about strengthening and improving the opinions of the construction of campus culture of colleges and universities, and China education news, 2004, vol. 6, pp. 12-13.

[5] D. T. Che, Ideology and humanistic care, Beijing: people's publishing house, 2012, vol. 5, pp. $39-43$.

[6] L. L Yao, The effectiveness research of ideological and political theory teaching, Theory of monthly, 2007, vol. 10, pp. 32-37

[7] D.L. Wang, About the strengthen and improvement in campus culture construction, China education daily, 2014, vol3, pp.9-13. 